RESENHAS 


\section{VASCONCELOS, Maurício Salles. Ela não fuma mais maconha São Paulo: Annablume, 2011. 292 p.}

Sabrina Sedlmayer Pinto Universidade Federal de Minas Gerais

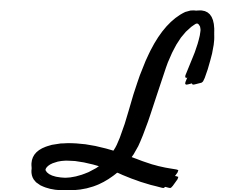

ançada em 2011, pelo selo literário [e]editorial, segmento da Annablume que arrisca e viabiliza obras inéditas de autores brasileiros, a narrativa Ela não fuma mais maconha, de Maurício Salles Vasconcelos, surpreende o leitor por pelo menos três motivos: primeiro, pela excelência do uso da língua (expressa, veloz, criativa); depois, pela densa e aguda construção da fragilidade de Alba, a protagonista, e seu viril e penoso jejum; em terceiro, por oferecer, subrepticiamente, sem pedantismo nem erudição panfletária, um mapa de leituras sólidas que faz com que a leitura se espraie, sem nenhum traço de abstinência, para além do vício do enredo e do enunciado.

Opto por começar a resenha por essa errância entre as vozes de outros. E a primeira que insurge é a de Cesário Verde. Desde 1998, Vasconcelos já havia deixado estampada a importância de Verde em sua formação poética ao publicar Ocidentes dum Sentimental (Editora Orobó). Nessa obra, demonstrou não apenas o seu atravessamento pelo incortonável poema de Cesário e o lugar cabal deste para a construção da sua própria poética, como, através de procedimentos experimentais que vão além dos empréstimos intertextuais, recriou espaços distintos da cartografia lisboeta e dilatou o sensorialismo. 
É comum repetir que foi Cesário quem singularizou, na literatura portuguesa, o tópos da cidade (e deu as costas ao mar, como laconicamente escreveu um dia Nuno Júdice). Mas a hipótese que levanto, ao cotejar Ocidentes dum sentimental com a narrativa Ela não fuma mais maconha, é que o que Vasconcelos valoriza no poeta português não é a celebração baudelairiana da flânerie, e sim a ação sofisticada de espacialização do tempo e de temporalização do espaço. Algo que Manuel Gusmão já alertara: "A cronotopia que Cesário constrói permite destacar na representação da cidade os dois movimentos contraditórios mas indissociáveis, que se aglutinam na própria palavra (cronotopia)." ${ }^{\prime 1}$

Nesse novo livro, Vasconcelos agudiza este traço e infla a esfera dos sentidos. O livro é todo sensorial, seja nas marcas intimistas das perambulações de Alba pelas pequenas e imaginadas cidades do interior do Vale do Aço, em Minas Gerais (Escarpa, Sebe, Atalho) ou no enclausuramento melancólico no modesto apartamento da capital. Por este aspecto, a vida ordinária de Alba, que em um determinado ponto da narrativa se diz ser "apenas um pedaço de gente (ou voz amorosa a se dirigir para qualquer um)", vida qualquer, nos remete à deriva dos personagens sem qualidades de João Gilberto Noll. Um quieto animal na esquina que, quando se apaixona por um clochard, um homeless, vive a fúria do corpo.

Alba, sem a erva - ou unzinho, skank, haxixe, hydro, crack, krypto, dentre tantos outros nomes prenhes de humor que o texto oferece para designar o fumo -, tem que aprender a viver sem a alteração da percepção costumeira. Nesse novo regime, se desconhece. Se numa visada ligeira a história da protagonista pode ser lida como uma busca identitária e profissional (transcritora, pesquisadora, ouvinte, mestranda,

${ }^{1}$ GUSMÃO, 2010, p. 220. 
quem sou sem a maconha?), o cigarro deixa de ser apenas vício e passa a integrar uma linhagem ontológica do desassossego, um "fio de fumo que atravessa a Europa literária do século XX", como disse Tabucchi a propósito de Fernando Pessoa. ${ }^{2}$

O uso intensivo do fumo vai de Lisboa a Trieste, de Álvaro de Campos a Ítalo Svevo. Nem só o ópio e o absinto foram intercessores da poesia decadentista e das vanguardas, podemos endossar. O cigarro, bom lembrar, é uma das marcas mais contundentes do Pessoa de "Tabacaria" e "Grandes são os desertos e tudo é deserto". Em alguns momentos relacionase ao desejo, em outros, ao obsessivo ritual, mas tange, principalmente, uma atividade intelectual, uma acirrada dialética entre o fora e o dentro, o real com e sem metafísica.

No caso de Ela não fuma mais maconha, há uma revisitação irônica, em tons de pastiche, da NatuRealeza, da natureza beleza, de uma época que já se foi e que nos deparamos, com vertigem, em alguns momentos, como quando estamos à frente da Coosmococas, de Hélio Oiticica, por exemplo. O make love, dont war, o amor livre entre amigos, a vida comunitária no campo longe dos ditames do politicamente correto e do consumo contemporâneo, tudo isso é repassado nesse livro de Maurício Salles Vasconcelos. Com ternura (mas cravado de melancolia), acompanhamos os passos de Alba e nos perguntamos por que ela não reacende logo a ponta.

\section{Referências bibliográficas}

TABUCCHI, António. Pessoana mínima. Lisboa: Casa da Moeda, 1983.

GUSMÃO, Manuel. Tatuagem E palimpsesto - da poesia em alguns poetas e poemas. Lisboa: Assírio \& Alvim, 2010.

2 TABUCCHI, 1984, p. 63. 